\title{
ARTICLE
}

\section{A Research on Threat (Hazard) Categorization Method for Nuclear Facilities}

\author{
TANG Rongyao* , XU Xiaoxiao, ZHANG Jiangang, ZHAO Bin, WANG Xuexin
}

China Institute for Radiation Protection, Taiyuan, P.R. China, 030006

\begin{abstract}
The threat categorization method suggested by International Atomic Energy Agency (IAEA) and hazard categorization standard by the Department of Energy of United States (USDOE) for nuclear facilities are compared and discussed in this paper. The research shows the two types of categorization method for nuclear facilities are similar, though each has its own specialty. The categorization method suggested by IAEA for the purpose of emergency planning is quite completed and updated. The categorization method of DOE is advanced in its operability, and fits for safety surveillance. But the dispersible radioactive material thresholds used for categorization need to be updated. The threshold of category 3 is somewhat disputable for many reasons. The recommended categorization method for China is also given in this paper.
\end{abstract}

KEYWORDS: nuclear facility, categorization, threat, hazard, safety surveillance, emergency

\section{Introduction}

Nuclear facility categorization is one of technical basis of safety supervision and emergency planning. Once the threat(hazard) category is defined, safety supervision and emergency preparedness could be carried out according to the hazards(threat) level.

There are two main threat (hazard) categorization methods. One is introduced in the publications of IAEA general safety series ${ }^{1-2)}$, which could be a minimal threat assessment in national level. The other is given in USDOE standard DOE-STD-1092 Hazard categorization and Accident Analysis Techniques for Compliance with DOE Order 5480.23, Nuclear Safety Analysis Reports. This standard is often quoted by reports, and also by regulations of DOE such as 10CFR830 and DOEO420 etc. It is an important part of graded approach applied in the safety surveillance of USDOE facilities. Different terms are used which are threat for IAEA, hazard for DOE. But both of the two methods are applicable to nuclear facility categorization. The two categorization methods are going to be compared and the suggestions on facility categorization in China will be given in this paper.

\section{Threat categories for nuclear facilities suggested by IAEA}

\section{Introduction of emergency threat categories} suggested by IAEA

Five categories are suggested by IAEA according to the threat of nuclear and radiological facilities ${ }^{1-2)}$. Threat category I , II and III represents decreasing levels of threat at major facilities and therefore correspond to decreasing stringency of requirements for emergency preparedness and response. Summary of threat categorization method of IAEA for nuclear facilities is given in Table 1. Category IV and V are more linked to nuclear activities rather than nuclear facilities, and omitted in table 1 . Also, the criteria $100 \mathrm{mGy} / \mathrm{h}$ of category III when lost shielding is mainly set for radioactive installation such as irradiation facility, which is not within the scope of nuclear facilities.

\section{Categorization criteria}

(1) Dispersible radioactive material lower threshold quantity(TQ)

The TQ are $10000 \mathrm{D} 2,100 \mathrm{D} 2$ and $0.01 \mathrm{D} 2$ for category I, II, III of nuclear facilities respectively. D2 is an important parameter in the categorization criteria ${ }^{4)}$. And D2 is the dangerous quantity of dispersible radioactive material which may cause permanent injury or could possibly be lethal. IAEA does not explain the origin of the threshold in detail for uncertainty, complexity and professional judgment in the deduction. However one can see that the different threshold between Category I and II are commensurate with the difference between reference dose level of severe deterministic health effect with reference level of urgent protection action. The lower threshold $0.01 \mathrm{D} 2$ of category III facilities is also the lower threshold of category IV dangerous source. No permanent injury will occur from dispersible radioactive material less than this quantity.

Inhalation and skin contact are the main pathways which cause health effect at most. There are 10 nuclides whose thresholds are given as one of tenth of the quantity of nuclear fissile material II in the consideration of nuclear safeguard.

The assumptions in the calculation used to set TQ are given in Table 2.

\section{(2) Threshold of reactor thermal power, criticality}

\section{threat and accident external dose rate}

The threshold of reactor thermal power is given according to the core melt accident consequence. Usually it is considered that core melt accident would not happen in reactors under $2 \mathrm{MW}($ th)(category III), and there is no need for off site emergency response. IAEA also points out that the category should be judged by actual situation of research reactor because of the diverse design.

*Corresponding author, Tel. +86-351-2202274,

Fax. +86-351-7020407, E-mail: tangrongyao@yahoo.com.cn 
Table 1 Summary of threat categorization method of IAEA for nuclear facilities

\begin{tabular}{|c|c|c|c|c|c|}
\hline \multirow{2}{*}{$\begin{array}{l}\text { Threat } \\
\text { Category }\end{array}$} & \multicolumn{5}{|l|}{ Criteria } \\
\hline & $\begin{array}{l}\text { Dispersible } \\
\text { radioactive } \\
\text { material inventory* } \\
\end{array}$ & Spent fuel & $\begin{array}{l}\text { Reactor } \\
\text { thermal power }\end{array}$ & $\begin{array}{l}\text { Potential criticality } \\
\text { accident }\end{array}$ & $\begin{array}{l}\text { External dose } \\
\text { rate }\end{array}$ \\
\hline I & $>10000 \mathrm{D} 2 * *$ & $\begin{array}{l}\text { Contain some recently } \\
\text { discharged fuel and a } \\
\text { total of more than about } \\
0.1 \mathrm{EBq} \text { of }{ }^{137} \mathrm{Cs}\end{array}$ & $>100 \mathrm{MW}$ & - & - \\
\hline II & $>100 \mathrm{D} 2$ & $\begin{array}{l}\text { Contain fuel requiring } \\
\text { active cooling }\end{array}$ & $\begin{array}{l}<100 \mathrm{MW} \text { and } \\
>2 \mathrm{MW}\end{array}$ & $\begin{array}{l}\text { Potential for an } \\
\text { uncontrolled criticality } \\
\text { on-site within } 0.5 \mathrm{~km} \\
\text { from the off-site } \\
\text { boundary }\end{array}$ & - \\
\hline III & $>0.01 \mathrm{D} 2$ & - & $<2 \mathrm{MW}$ & $\begin{array}{l}\text { Potential for an } \\
\text { uncontrolled criticality } \\
\text { on-site over } 0.5 \mathrm{~km} \text { from } \\
\text { the off-site boundary }\end{array}$ & $\begin{array}{l}100 \mathrm{mGy} / \mathrm{h} \text { at } 1 \\
\mathrm{~m} \text { if shielding } \\
\text { lost }\end{array}$ \\
\hline
\end{tabular}

*If $10 \%$ of the inventory is assumed to be released to the atmosphere, for threat category I,II,III facility, emergencies have been postulated that could result in severe deterministic health effects off site, result in doses warranting taking urgent protective action offsite, or doses warranting taking urgent protective action on site respectively.

** D2 is the dangerous quantity of dispersible radioactivity material given by IAEA.

Table 2 Summary of the assumptions in setting TQ of IAEA

\begin{tabular}{|c|c|c|c|c|c|c|}
\hline $\begin{array}{r}\text { Threat } \\
\text { Category }\end{array}$ & $\begin{array}{l}\text { Release } \\
\text { fraction of } \\
\text { the material } \\
\text { at risk }\end{array}$ & $\begin{array}{l}\text { Receptor } \\
\text { position }\end{array}$ & $\begin{array}{l}\text { Exposure } \\
\text { pathway }\end{array}$ & $\begin{array}{l}\text { Exposure } \\
\text { duration }\end{array}$ & $\begin{array}{l}\text { Atmosphere } \\
\text { condition }\end{array}$ & Radioactive consequence \\
\hline I & $\begin{array}{l}10 \% \text { of the } \\
\text { total }\end{array}$ & $\begin{array}{l}\text { Around } \\
250 \mathrm{~m} \\
\text { downwind }\end{array}$ & $\begin{array}{l}\text { Inhalation } \\
\text { Ingestion } \\
\text { Skin } \\
\text { Contamination } \\
\text { Immersion }\end{array}$ & $12 \mathrm{hrs}$ & $\begin{array}{l}\text { Average } \\
\text { meteorological } \\
\text { conditions }\end{array}$ & $\begin{array}{l}\text { Severe Heath effect } \\
\text { offsite(acute bone marrow } \\
\text { dose greater than } 2 \text { Gy etc.) }\end{array}$ \\
\hline II & $\begin{array}{l}\text { Same as } \\
\text { above }\end{array}$ & $\begin{array}{l}\text { Around } \\
250 \mathrm{~m} \\
\text { downwind }\end{array}$ & Same as above & $\begin{array}{l}\text { Same as } \\
\text { above }\end{array}$ & Same as above & $\begin{array}{l}\text { Warrant urgent protective } \\
\text { action offsite }(10 \mathrm{mSv} \text { for } \\
\text { shielding etc.) }\end{array}$ \\
\hline III & $\begin{array}{l}\text { Same as } \\
\text { above }\end{array}$ & $\begin{array}{l}\text { In the } \\
\text { workshop }\end{array}$ & Same as above & $\begin{array}{l}\text { A few } \\
\text { minutes }\end{array}$ & - & $\begin{array}{l}\text { Warrant urgent protective } \\
\text { action on site(cleanup etc.) }\end{array}$ \\
\hline
\end{tabular}

The distance between criticality accident scene and site boundary is another criterion for setting nuclear threat category. If the distance is less that $500 \mathrm{~m}$, it is category II. If more than $500 \mathrm{~m}$, category III it is. The assumption for the accident is: the criticality accident with a total $1 \times 10^{19}$ fissions causes $10 \mathrm{mSv}$ to a person at $300 \mathrm{~m}$ far from the accident point.

If the dose rate could approach $100 \mathrm{mGy} / \mathrm{h}$ at $1 \mathrm{~m}$ when shielding lost, Facility is category III. When the dose to workers nearby could approach to dozens of $\mathrm{mSv}$ in several tens of minutes, and it warrant urgent protection action.

Through the explanation we can conclude that above criteria are given by the radioactive consequences of the most severe accidents, which are commensurate with the criteria of radioactive material thresholds.

\section{Nuclear facility hazard categorization method of USDOE \\ 1. Introduction of USDOE nuclear facility hazard categorization method}

Four categories of facility were defined In DOE-STD-1027 $7^{5)}$. Summary of hazard categorization method of USDOE for nuclear facilities is given in Table 3.

Hazard Category 1: Hazard Analysis shows the potential for significant off-site consequences, which include Category A reactors (steady-state power level greater than 20MWth and facilities designated by Program Secretarial Officers . 
Table 3 Summary of threat categorization method of USDOE for nuclear facilities

\begin{tabular}{|l|l|l|l|}
\hline Category & $\begin{array}{l}\text { Dispersible } \\
\text { radioactive } \\
\text { material threshold } \\
\text { quantity(DMTQ) }\end{array}$ & $\begin{array}{l}\text { Reactor } \\
\text { thermal level }\end{array}$ & $\begin{array}{l}\text { Criticality } \\
\text { safety }\end{array}$ \\
\hline 1 & - & $>20 \mathrm{MW}($ th) & - \\
\hline 2 & $\begin{array}{l}>\mathrm{TQ} 2^{*} \text { or } \\
>1000 \mathrm{Ci}\end{array}$ & $>0 \mathrm{MW}(\mathrm{th})$ & $\begin{array}{l}\text { Potential } \\
\text { to critical } \\
\text { accident }\end{array}$ \\
\hline 3 & $>\mathrm{TQ} 3 * *$ & - & - \\
\hline Below 3 & $>\mathrm{RQ} * *$ & - & - \\
\hline
\end{tabular}

*TQ2 is the lower threshold quantity for category 2 .

**TQ3 is the lower threshold quantity for category 3 .

$* * * \mathrm{RQ}$ is the reportable quantity set by environment protection agency(EPA)

Hazard Category 2: Hazard Analysis shows the potential for significant on-site consequences. Facilities with the potential for nuclear criticality events or with sufficient quantities of hazardous material and energy, which would require on-site emergency planning activities.

Hazard Category 3: Hazard Analysis shows the potential for significant but localized consequences. Facilities with quantities of hazardous radioactive materials, which meet or exceed the Category 3 threshold. Usually it includes laboratory, low level radioactive waste storage facility etc.

Facilities that do not meet or exceed Category 3 threshold criteria but still possess some amount of radioactive material (which is called report quantity(RQ)) may be considered as Radiological Facilities. RQ is the amount of radioactive material which may cause $5 \mathrm{mSv}$ dose at $30 \mathrm{~m}$ downwind in an accident ${ }^{6)}$, and it's given by Environment Protection Agency (EPA).

\section{Origin of DOE hazard categorization criteria}

According to the principle explained above, DOE calculated the threshold quantity TQ2 of dispersible radioactive material for category 2 and TQ3 on the base of EPA RQ calculation(roughly, it's 20 times RQ). The assumptions taken in the calculation are put in Table 4.

Explanations of the reactor thermal power level threshold have not been found. It can be seen that the complexity of reactor compared to other nuclear facilities adds weight to its categorization. Also criticality safety is paid special attention besides radiation safety.

Table 4 Assumptions in calculating TQ2 and TQ3 of USDOE

\begin{tabular}{|l|l|l|l|l|l|}
\hline Category & Receptor position & $\begin{array}{l}\text { Radioactive } \\
\text { consequenc }\end{array}$ & Exposure pathway & $\begin{array}{l}\text { Release fraction of } \\
\text { the material at risk }\end{array}$ & Atmosphere condition \\
\hline 2 & $\begin{array}{l}\text { at } 300 \mathrm{~m} \\
\text { downwind* }\end{array}$ & $10 \mathrm{mSv}$ & $\begin{array}{l}\text { inhalation and } \\
\text { immersion }\end{array}$ & $\begin{array}{l}\text { based on the data } \\
\text { from NUREG-1140 }\end{array}$ & $\begin{array}{l}\text { under average } \\
\text { meteorological } \\
\text { conditions }\end{array}$ \\
\hline 3 & at 30m downwind & $100 \mathrm{mSv}$ & $\begin{array}{l}\text { external exposure, } \\
\text { ingestion, } \\
\text { inhalation, } \\
\text { drinking }{ }^{6} .\end{array}$ & From NUREG-1140 & $\begin{array}{l}\text { under reserve } \\
\text { meteorological } \\
\text { condition }\end{array}$ \\
\hline Below 3 & at 30m downwind & $5 \mathrm{mSv}$ & $\begin{array}{l}\text { external exposure, } \\
\text { ingestion, } \\
\text { inhalation, } \\
\text { drinking. }\end{array}$ & From NUREG-1140 & $\begin{array}{l}\text { under reserved climate } \\
\text { condition }\end{array}$ \\
\hline
\end{tabular}

*Though DOE claimed the dose is at 100m downwind, Actually the dispersion coefficient used in calculation is the value at $300 \mathrm{~m}$ downwind under average climate condition $^{5-6)}$.

\section{Comparison and discussion}

\section{Similarity}

Categorization criteria of IAEA and USDOE are both given by inventory of dispersible radioactive material inventory, reactor thermal power level, criticality consideration.

The way of calculating TQ2 of USDOE is similar as that of category II of IAEA, which result in the threshold similarity of some nuclides(see Table 5). The difference mainly comes from the dose factor and the release factor of nuclides in the accident. The dose factors of USDOE were taken from ICRP-30, while IAEA from ICRP-68 and 72.

\section{Difference}

Application purposes are the main differences. The potential nuclear and radioactive consequence is the main consideration of IAEA. While for DOE, besides hazards level, the complexity of facility, the diversity of research reactor and flexibility in safety surveillance are also concerns for safety officers.

Table 5 TQ Comparison of IAEA and USDOE(partial)

\begin{tabular}{|c|c|c|c|c|}
\hline \multirow{2}{*}{ Nuclide } & \multicolumn{2}{|c|}{ TQ2(TBq) } & \multicolumn{2}{c|}{ TQ3(TBq) } \\
\cline { 2 - 5 } & DOE & IAEA & DOE & IAEA \\
\hline P-32 & $1.63 \mathrm{E}+02$ & $2.00 \mathrm{E}+03$ & $4.44 \mathrm{E}-01$ & $2.00 \mathrm{E}-01$ \\
\hline $\mathrm{Co}-60$ & $7.03 \mathrm{E}+03$ & $3.00 \mathrm{E}+03$ & $1.04 \mathrm{E}+01$ & $3.00 \mathrm{E}-01$ \\
\hline $\mathrm{Kr}-85$ & $1.04 \mathrm{E}+06$ & $2.00 \mathrm{E}+05$ & $7.40 \mathrm{E}+02$ & $2.00 \mathrm{E}+01$ \\
\hline Sr-90 & $8.14 \mathrm{E}+02$ & $1.00 \mathrm{E}+02$ & $5.92 \mathrm{E}-01$ & $1.00 \mathrm{E}-02$ \\
\hline Cs-137 & $3.29 \mathrm{E}+03$ & $2.00 \mathrm{E}+03$ & $2.22 \mathrm{E}+00$ & $2.00 \mathrm{E}-01$ \\
\hline
\end{tabular}

TQ3 of Category III of IAEA are lower compared with USDOE category 3 . This comes from the different principle 
and different scenario in setting TQ3.

\section{Discussion}

For nuclear emergency response arrangement of civil nuclear facilities on national level, IAEA categorization method is rational. The new research results of radiobiological effect, emergency intervention level and historical experience of radiation source accident are considered in TQ calculation.

For safety surveillance purpose, The advantages of IAEA and USDOE should be combined. At the same time consistency of categorization basis must be kept. Beside potential hazards level, complexity of safety related items must be considered. Flexibility is also needed sometimes which requires judgment case by case.
A recommended categorization method for safety surveillance is given in Table 6.

The criteria of reactor thermal power level and criticality accident of USDOE are kept in the consideration of diversity of research reactor and complexity of criticality safety control.

The TQ2 of USDOE needs to be updated. The basis of USDOE TQ3 is also quite disputable. TQ3 of USDOE is linked to RQ of EPA for the consistency of regulations. But this is not necessarily the case in China. In this case, TQ of IAEA is recommended and revised in the consideration of appropriate safety surveillance.

Table 6 Recommended categorization method for safety surveillance

\begin{tabular}{|l|l|l|l|l|}
\hline category & $\begin{array}{l}\text { Dispersible material } \\
\text { threshold quantity }\end{array}$ & $\begin{array}{l}\text { Reactor thermal } \\
\text { power }\end{array}$ & $\begin{array}{l}\text { Potential critical } \\
\text { accident }\end{array}$ & Main requirement of safety analysis \\
\hline 1 & $10000 \mathrm{D} 2$ & - & $\begin{array}{l}\text { Probabilistic Safety } \\
\text { Analysis(PSA)\&Environment Statement(ES) } \\
\text { required }\end{array}$ \\
\hline 2 & $100 \mathrm{D} 2$ & $>=0 \mathrm{MW}(\mathrm{th})$ & $\begin{array}{l}\text { Potential } \\
\text { critical accident }\end{array}$ & Quantitative SA \& ES required \\
\hline 3 & D2 & - & - & Qualitative SA \& ES required \\
\hline
\end{tabular}

\section{Reference}

1) Emergency Preparedness and Response for a Nuclear or Radiological, GS-R-2, INTERNATIONAL ATOMIC ENERGY AGENCY, VIENNA, 2002

2) Arrangements for preparedness for a nuclear or radiological emergency. Safety Guide, No.GS-G-2.1, INTERNATIONAL ATOMIC ENERGY AGENCY, VIENNA, 2007

3) IAEA. Method for Developing Arrangements for Response to a Nuclear or Radiological Emergency Updating IAEA-TECDOC-953. EPR-METHOD. INTERNATIONAL ATOMIC ENERGY AGENCY, VIENNA, 2003

4) IAEA. Dangerous quantities of radioactive material(D-values).
EPR-D-VALUES. INTERNATIONAL ATOMIC ENERGY AGENCY, VIENNA, 2006

5) Hazard categorization and accident analysis techniques for compliance with DOE order 5480.23. Nuclear safety analysis reports. DOE-STD-1027-92. U.S. Department of Energy. 1997

6) Mandigo R L, Evans C B . Category 3 Threshold Quantities for Hazard Categorization of Nonreactor Facilities. Document \#:SD-GN-HC-20002, Westinghouse Hanford Company. 1996

7) S.A.McGuire, A Regulatory Analysis on Emergency Preparedness for Fuel Cycle and Other Radioactive Material Licensees. NUREG-1140.NRC.1987 